\title{
List of film scenes
}

Descending with angels, ethnographic documentary, $75 \mathrm{~min}$.

Filmed and edited by Christian Suhr, Persona Film, 2013.

For readers of this book, the film Descending with angels can be accessed at the website www.descendingwithangels.com with the password: ruqya.

To purchase the film for public or classroom use contact Documentary Educational Resources

Phone: (617) 926-0491 | orders@der.org | www.der.org.

I Rain at night-time, Aarhus Vest, prayer in the mosque (qiyäm al-layl).

2 Shaykh Abu Bilal exorcising a jinn, Abu Omar's apartment: 2:59.

3 Noon prayer (șalät al-zuhur) performed by Nour Aziz who then explains his problems with magic and psychiatry: II:38.

4 Monthly meeting: Aziz discusses his illness with his psychiatrist Jørgen Aagaard, Aarhus University Hospital, Risskov: I5:32.

5 Abu Bilal examines a young woman for possession by jinn: 21:I6.

6 Esther Isaksen, Jørgen Aagaard, and Christian Suhr watch and discuss the film recordings, Aarhus University Hospital, Risskov: 29:2 I.

7 Young Muslims watch and discuss a YouTube video entitled '7000 year old jinn inside man', Brabrand: 32:59.

8 Weekly meeting: Aziz discusses his condition and the effects of psychotropic medication with his nurse Esther, Aarhus University Hospital, Risskov: 40:52.

9 Abu Bilal and Christian watch the film recordings: Abu Bilal explains his views on illness and psychotropic medication: 44:59.

IO Lecture about Quranic healing in the mosque, Society for Equality and Brotherhood, Brabrand: 48:04.

II Esther and Christian discuss the exorcism of Abu Omar and reasons why the jinn did not speak: 5I:25.

I2 Abu Bilal, Abu Bashir, Umm Omar, and Abu Omar evaluate the exorcism of Abu Omar's jinn and Abu Bilal performs additional reading: 53:57.

I3 Esther and Christian talk about the possible dangers of exorcism and psychiatry. Esther argues for the necessity of care in healing: 1:03:27.

I4 Monthly meeting: Jørgen, Esther, and Birte Gam explain the necessity of continued medication to Aziz and also acknowledge the healing effect of Aziz's religious practice: r:05:32.

I5 Evening prayer during Ramadan (șalāt al-tarāin̄h $)$ I:I3:38. 